\title{
Pulses of enhanced North Pacific Intermediate Water ventilation from the Okhotsk Sea and Bering Sea during the last deglaciation
}

\author{
L. Max ${ }^{1}$, L. Lembke-Jene ${ }^{1}$, J.-R. Riethdorf ${ }^{2}$, R. Tiedemann ${ }^{1}$, D. Nürnberg ${ }^{2}$, H. Kühn ${ }^{1}$, and A. Mackensen ${ }^{1}$ \\ ${ }^{1}$ Alfred-Wegener-Institut, Helmholtz-Zentrum für Polar- und Meeresforschung, Am Handelshafen 12, \\ 27570 Bremerhaven, Germany \\ ${ }^{2}$ GEOMAR, Helmholtz-Zentrum für Ozeanforschung Kiel, Wischhofstr. 1-3, 24148 Kiel, Germany
}

Correspondence to: L. Max (lars.max@awi.de)

Received: 11 October 2013 - Published in Clim. Past Discuss.: 7 November 2013

Revised: 13 February 2014 - Accepted: 13 February 2014 - Published: 21 March 2014

\begin{abstract}
Under modern conditions only North Pacific Intermediate Water is formed in the northwest Pacific Ocean. This situation might have changed in the past. Recent studies with general circulation models indicate a switch to deep-water formation in the northwest Pacific during Heinrich Stadial $1(17.5-15.0 \mathrm{ka})$ of the last glacial termination. Reconstructions of past ventilation changes based on paleoceanographic proxy records are still insufficient to test whether a deglacial mode of deep-water formation in the North Pacific Ocean existed. Here we present deglacial ventilation records based on radiocarbon-derived ventilation ages in combination with epibenthic stable carbon isotopes from the northwest Pacific including the Okhotsk Sea and Bering Sea, the two potential source regions for past North Pacific ventilation changes. Evidence for most rigorous ventilation of the intermediatedepth North Pacific occurred during Heinrich Stadial 1 and the Younger Dryas, simultaneous to significant reductions in Atlantic Meridional Overturning Circulation. Concurrent changes in $\delta^{13} \mathrm{C}$ and ventilation ages point to the Okhotsk Sea as driver of millennial-scale changes in North Pacific Intermediate Water ventilation during the last deglaciation. Our records additionally indicate that changes in the $\delta^{13} \mathrm{C}$ intermediate-water (700-1750 $\mathrm{m}$ water depth) signature and radiocarbon-derived ventilation ages are in antiphase to those of the deep North Pacific Ocean (> $2100 \mathrm{~m}$ water depth) during the last glacial termination. Thus, intermediate- and deepwater masses of the northwest Pacific have a differing ventilation history during the last deglaciation.
\end{abstract}

\section{Introduction}

Today, the renewal of North Pacific Intermediate Water (NPIW) is mainly coupled to physical processes in the Okhotsk Sea (Talley and Roemmich, 1991; Talley, 1993), where Dense Shelf Water is produced in coastal polynyas by brine rejection during wintertime sea-ice production (Shcherbina et al., 2003). These water masses leave the Okhotsk Sea as Okhotsk Sea Intermediate Water (OSIW), mix with water masses in the northwest Pacific at intermediate depths and form NPIW (Yasuda, 1997). The NPIW spreads eastward through the North Pacific Ocean between $\sim 20-40^{\circ} \mathrm{N}$. Its easternmost extension is located in the vicinity of the California Current region, where it can still be recognized as a well-defined water mass of higher oxygen concentrations between $\sim 300-800 \mathrm{~m}$ water depths (Talley, 1993). No deep water is formed in the modern subarctic Pacific, as surface waters are isolated from the highly nutrientrich waters below by a steep salinity gradient (permanent halocline), which leads to a robust stratification of the surface ocean in this region. The deep North Pacific is only slowly replenished by Southern Ocean water masses due to the absence of deep-water formation in the North Pacific Ocean today (Warren, 1983; Emile-Geay et al., 2003).

Several studies with general circulation models (GCMs) point to fundamental changes in deep Pacific hydrography and circulation during the last deglaciation (Mikolajewicz et al., 1997; Schmittner et al., 2007; Okumura et al., 2009; Okazaki et al., 2010; Chikamoto et al., 2012; Menviel et al., 2012). A few model simulations show an onset of deep-water formation to a depth of $\sim 2500-3000 \mathrm{~m}$ in the northwest 
Pacific during deglacial cold events Heinrich Stadial 1 (HS1) and the Younger Dryas (YD) due to a breakdown of the density-driven stratification (Okazaki et al., 2010; Menviel et al., 2012). In these scenarios, a weakening of the Atlantic Meridional Overturning Circulation (AMOC) and associated North Atlantic cooling leads to a reduced Atlantic-Pacific moisture transport by shifting the Pacific Intertropical Convergence Zone further south. This facilitates a reduction of precipitation and hence an overall increase of surface salinity in the North Pacific. Once the Pacific meridional overturning cell (PMOC) spins up, a more rigorous poleward transport of surface currents carries warm and saline subtropical waters further north providing a positive salinity feedback. The PMOC is proposed to play an important role in buffering the decrease in the poleward global oceanic heat transport by a larger northward advection of subtropical waters into the subarctic Pacific (Okazaki et al., 2010). The physical mechanism behind this effect is the positive feedback between salinity anomalies and ocean circulation known as Stommel feedback (Saenko et al., 2004). In contrast, sea surface temperature (SST) records from the northwest Pacific suggest no shift in poleward oceanic heat transport during these intervals (Harada et al., 2012; Max et al., 2012). Hence, the role of the PMOC in destabilizing the density-driven stratification by buffering the decrease in poleward global oceanic heat transport and associated larger northward advection of saline subtropical waters into the subarctic Pacific during HS- 1 and the YD seems to have been overestimated by model simulations. This would be consistent with proxy data from the deep North Pacific, which indicate no direct deep-water ventilation during the last deglaciation (Lund et al., 2011; Jaccard and Galbraith, 2013; Lund, 2013). However, anomalously young water masses have been recently reported from a deep-sea core in the Gulf of Alaska during HS-1 and point to at least some regional changes of deep circulation in the northeast Pacific Ocean (Sarnthein et al., 2013).

Information on deglacial changes in northwest Pacific intermediate-water ventilation is available from a few sediment records (1000-1300 m water depth) located at the eastern coast of Japan based on ventilation ages. Radiocarbon ages between coeval planktic and benthic foraminifers (defined as ventilation ages) were used to measure the difference in the ${ }^{14} \mathrm{C}$ to $\mathrm{C}$ ratio in the dissolved inorganic carbon between surface water and deep water to provide ventilation age changes of the deep water (Broecker et al., 2004). It has been shown that ventilation ages are reduced during HS-1 and the YD and point to a better ventilation of NPIW (Duplessy et al., 1989; Ahagon et al., 2003; Sagawa and Ikehara, 2008). However, necessary information on ventilation changes from shallower sites in the northwest Pacific are not available and important aspects about the mode of formation of deglacial NPIW as well as the respective roles of the Bering Sea or the Okhotsk Sea as possible source regions of NPIW are not well known. Available studies on circulation changes from these key regions alternatively point to the Bering Sea (Horikawa et al., 2010; Rella et al., 2012) or the Okhotsk Sea (Tanaka and Takahashi, 2005; Okazaki et al., 2014) as major contributor of enhanced NPIW formation in the past. Another crucial aspect is the timing of deglacial circulation changes in the northwest Pacific. Based on model simulations with GCMs a rapid switch and a seesaw pattern between changes in Pacific and Atlantic overturning circulation cells prevailed during the last deglaciation (Okazaki et al., 2010). However, high-resolution proxy records of millennial-scale ventilation changes in the northwest Pacific that include the high-latitude marginal seas are still missing and impede the understanding of potential relationships and interactions between Pacific and Atlantic circulation changes during the last deglaciation.

Here we present a detailed view on deglacial northwest Pacific circulation changes by providing new proxy data derived from epibenthic $\delta^{13} \mathrm{C}$ measurements indicative of differences in past seawater nutrient and oxygen level in combination with a suite of new ventilation ages from sediment cores collected in the northwest Pacific and its marginal seas (Biebow et al., 2002; Dullo et al., 2004; Dullo et al., 2009; Gersonde, 2012) (Fig. 1). From this we constrain: (1) the link between ventilation changes in the open northwest Pacific and its marginal seas; (2) the temporal relationship of ventilation changes to variations in AMOC; (3) whether ventilation changes in the Okhotsk Sea, Bering Sea or both represent the major source of enhanced NPIW during the last deglaciation. In this paper we follow the terminology of Talley et al. (2003) and refer to the intermediate-depth layer of the North Pacific covering the depth range of $>500-2000 \mathrm{~m}$ water depth and the deep North Pacific covering water depths $>2000 \mathrm{~m}$.

\section{Material and methods}

\subsection{Measurements of $\delta^{13} \mathrm{C}_{\mathrm{DIC}}$ of seawater}

Modern vertical distribution of $\delta^{13} \mathrm{C}_{\mathrm{DIC}}$ throughout the water column was derived from two hydrocast stations proximal to the Bering Sea core SO201-2-85KL (SO201-2-67; 56 $04^{\prime} \mathrm{N}$, $169^{\circ} 14^{\prime}$ E) and Okhotsk Sea core SO178-13-6 (LV29-843; $52^{\circ} 42^{\prime} \mathrm{N}, 144^{\circ} 13^{\prime} \mathrm{E}$ ) (Fig. 1). Samples were collected during the joint German-Russian expeditions LV29 of R/V Akademik M. A. Lavrentyev in 2002 to the Okhotsk Sea (Biebow et al., 2002) and SO201-2 of R/V Sonne in 2009 to the Bering Sea (Dullo et al., 2009) via a rosette water sampling system. Water samples were poisoned with a saturated solution of $\mathrm{HgCl}_{2}$ to stop biological activity, sealed airtight, and stored at $4{ }^{\circ} \mathrm{C}$ temperature until further treatment. Bering Sea samples were measured with a Finnigan Gas Bench II coupled to a Finnigan MAT 252 mass spectrometer for determination of stable carbon isotope ratio at the Alfred Wegener Institute in Bremerhaven (AWI). Measurements of the $\delta^{13} C_{\text {DIC }}$ from Okhotsk Sea samples were carried out in the Leibniz Laboratory for Radiometric Dating and Isotope 


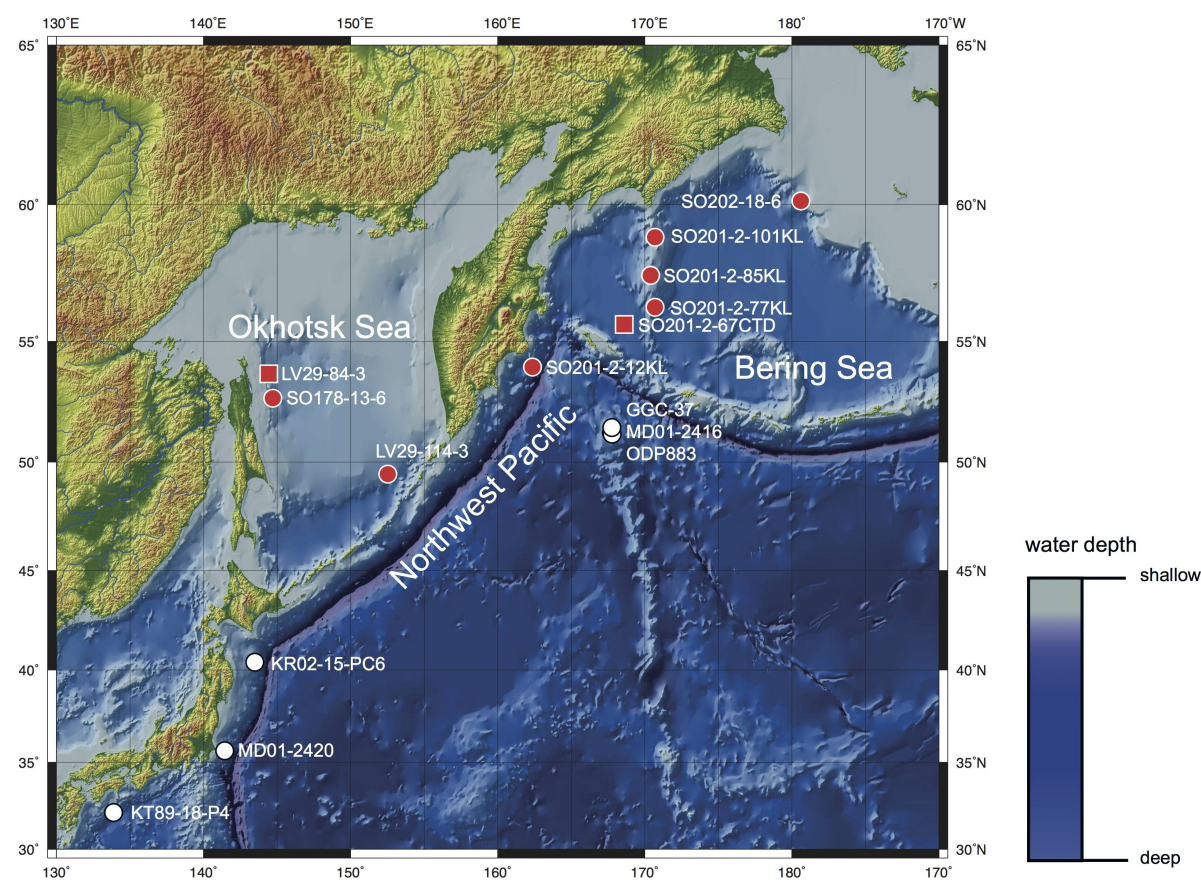

Fig. 1. Overview of the subarctic northwest Pacific and its marginal seas (Okhotsk Sea and Bering Sea). Red spots indicate core locations and red squares mark hydrocast stations obtained in this study. White spots show published sediment cores from the northwest Pacific realm considered in this study (please see Tables 2 and 3 as well as references therein).

Research in Kiel, using an automated Kiel DICI-II device for $\mathrm{CO}_{2}$ extraction and a Finnigan MAT Delta E mass spectrometer according to established procedures (Erlenkeuser et al., 1995; Erlenkeuser et al., 1999). Results are given in $\delta$ notation versus VPDB. The precision of $\delta^{13} \mathrm{C}_{\text {DIC }}$ measurements based on internal laboratory standards has been reported to be better than $\pm 0.1 \%$ at both laboratories.

\subsection{Benthic stable carbon isotope records $\left(\delta^{13} \mathrm{C}\right)$}

Stable carbon isotope records $\left(\delta^{13} \mathrm{C}\right)$ derived from tests of epibenthic foraminifera have been long documented as robust proxy to trace past variations in deep-water circulation since it is closely linked to ambient seawater $\delta^{13} \mathrm{C}_{\mathrm{DIC}}$ nutrient- and oxygen levels (Belanger et al., 1981; Duplessy et al., 1984; Curry et al., 1988; Curry and Oppo, 2005). In general, high(low) $\delta^{13} \mathrm{C}_{\text {DIC }}$ values are indicative of low(high) nutrient concentrations and associated changes in ocean circulation (Kroopnick, 1985). For stable isotope analysis, we only used specimens of the epibenthic species Cibicides lobatulus (C. lobatulus) from the $250-500 \mu \mathrm{m}$ fraction. Some studies have observed a positive offset in the $\delta^{13} \mathrm{C}$ of this species with regard to ambient bottom water for $\delta^{13} \mathrm{C}$ at the time of sampling in other high-latitude settings. However, this effect was shown to be likely caused by high seasonal variability of the ambient water $\delta^{13} \mathrm{C}$-signal as indicated by time-series measurements of water column $\delta^{13} \mathrm{C}$ and according calcification of $C$. lobatulus during time intervals of maximum ventilation (Mackensen et al., 2000).

Prior to stable isotope determination, sediment samples from cores SO178-13-6 (Okhotsk Sea) and SO201-2-85KL (western Bering Sea) (Fig. 1) were freeze-dried, wet sieved at $63 \mu \mathrm{m}$, dried and separated in several sub-fractions (63$150,150-250,250-500,>500 \mu \mathrm{m})$. If possible, we picked three to five specimens per sample and restricted our selection to well-preserved specimen with visible pores, clear sutures and unfilled chambers. During some intervals with low benthic foraminiferal abundance, single specimens were used for analysis.

Samples from core SO178-13-6 were measured with a Thermo Finnigan MAT 252 isotope ratio mass spectrometer coupled to an automated KIEL II CARBO preparation device at the GEOMAR - Helmholtz Centre for Ocean Research in Kiel. Samples from core SO201-2-85KL were measured with a Thermo Finnigan MAT 253 isotope ratio mass spectrometer coupled to an automated KIEL IV CARBO preparation device at the Stable Isotope Laboratory at the AWI. Overall analytical reproducibility of laboratory standards (Solnhofen limestone) measured together with samples over one year for $\delta^{13} \mathrm{C}$ is better than $\pm 0.06 \%$ at both laboratories. Calibration was achieved via National Bureau of Standards NBS19 international standard versus VPDB (Table 1). 
Table 1. Stable isotope measurement results $\left(\delta^{18} \mathrm{O} ; \delta^{13} \mathrm{C}\right)$ derived from epibenthic foraminifera Cibicides lobatulus.

\begin{tabular}{|c|c|c|c|c|}
\hline Core & $\begin{array}{l}\text { Core } \\
\text { depth } \\
(\mathrm{cm})\end{array}$ & $\begin{array}{c}\text { Age } \\
(\mathrm{kaBP})\end{array}$ & $\begin{array}{c}\delta^{18} \mathrm{O} \\
(\% \circ \mathrm{PDB})\end{array}$ & $\begin{array}{c}\delta^{13} \mathrm{C} \\
(\% \circ \mathrm{PDB})\end{array}$ \\
\hline \multirow[t]{23}{*}{ SO201-2-85KL (western Bering Sea) } & 43 & 11.12 & 3.440 & -0.500 \\
\hline & 45 & 11.23 & 3.288 & -0.350 \\
\hline & 50 & 11.50 & 3.117 & -0.424 \\
\hline & 53 & 11.79 & 3.360 & -0.230 \\
\hline & 55 & 12.14 & 3.387 & -0.200 \\
\hline & 60 & 13.01 & 3.461 & -0.349 \\
\hline & 63 & 13.29 & 3.323 & -0.388 \\
\hline & 80 & 14.76 & 3.307 & -0.428 \\
\hline & 81 & 14.83 & 3.670 & -0.056 \\
\hline & 85 & 15.13 & 3.481 & -0.185 \\
\hline & 95 & 15.96 & 3.988 & -0.125 \\
\hline & 100 & 16.45 & 4.536 & -0.034 \\
\hline & 103 & 16.75 & 3.640 & -0.210 \\
\hline & 105 & 16.94 & 4.231 & -0.035 \\
\hline & 110 & 17.44 & 3.256 & -0.441 \\
\hline & 113 & 17.73 & 3.960 & -0.260 \\
\hline & 115 & 17.93 & 3.817 & -0.401 \\
\hline & 120 & 18.42 & 4.121 & -0.335 \\
\hline & 123 & 18.72 & 3.930 & -0.450 \\
\hline & 125 & 18.91 & 3.965 & -0.425 \\
\hline & 130 & 19.41 & 3.839 & -0.232 \\
\hline & 131 & 19.51 & 3.864 & -0.227 \\
\hline & 133 & 19.70 & 3.900 & -0.210 \\
\hline \multirow[t]{30}{*}{ SO178-13-6 (Okhotsk Sea) } & 1767.5 & 11.55 & 3.74 & -0.33 \\
\hline & 1772.5 & 11.58 & 3.45 & -0.27 \\
\hline & 1822.5 & 11.92 & 3.59 & 0.12 \\
\hline & 1842.5 & 12.05 & 3.48 & 0.27 \\
\hline & 1857.5 & 12.15 & 3.59 & 0.48 \\
\hline & 1870.5 & 12.33 & 3.66 & 0.15 \\
\hline & 1885.5 & 12.54 & 3.38 & 0.64 \\
\hline & 1912.5 & 12.92 & 3.43 & 0.48 \\
\hline & 1917.5 & 12.98 & 3.22 & 0.16 \\
\hline & 1922.5 & 13.05 & 3.39 & 0.04 \\
\hline & 1937.5 & 13.26 & 3.26 & -0.67 \\
\hline & 1972.5 & 14.51 & 4.07 & -0.44 \\
\hline & 2087.5 & 14.95 & 3.1 & 0.81 \\
\hline & 2092.5 & 15.06 & 3.05 & 0.28 \\
\hline & 2157.5 & 15.43 & 3.81 & 0.29 \\
\hline & 2162.5 & 15.50 & 4.04 & 0.04 \\
\hline & 2177.5 & 15.68 & 4.05 & 0.42 \\
\hline & 2187.5 & 15.81 & 3.82 & 0.21 \\
\hline & 2202.5 & 16.00 & 3.88 & 0.12 \\
\hline & 2242.5 & 16.25 & 3.9 & 0.46 \\
\hline & 2247.5 & 16.28 & 3.81 & 0.08 \\
\hline & 2252.5 & 16.38 & 3.86 & 0.11 \\
\hline & 2272.5 & 16.47 & 3.78 & 0.21 \\
\hline & 2277.5 & 16.57 & 3.88 & 0.31 \\
\hline & 2292.5 & 16.66 & 3.64 & 0.48 \\
\hline & 2297.5 & 16.76 & 4.12 & 0.48 \\
\hline & 2307.5 & 16.85 & 3.75 & 0.66 \\
\hline & 2317.5 & 16.95 & 3.11 & -0.19 \\
\hline & 2327.5 & 17.11 & 3.94 & 0.21 \\
\hline & 2342.5 & 17.20 & 3.99 & 0.27 \\
\hline
\end{tabular}




\subsection{X-ray fluorescence (XRF) measurements}

XRF measurements were conducted on core SO178-13-6 at the Center for Marine Environmental Science (MARUM), Bremen. Each core segment was double-scanned for element analysis at $1 \mathrm{~mA}$ and tube voltages of $10 \mathrm{kV}(\mathrm{Al}, \mathrm{Si}, \mathrm{S}, \mathrm{K}$, $\mathrm{Ca}, \mathrm{Ti}, \mathrm{Fe})$ and $50 \mathrm{kV}(\mathrm{Ag}, \mathrm{Cd}, \mathrm{Sn}, \mathrm{Te}, \mathrm{Ba})$ using a sampling resolution of $1 \mathrm{~cm}$ and $30 \mathrm{~s}$ count time.

\subsection{Radiocarbon dating $\left(\mathrm{AMS}{ }^{14} \mathrm{C}\right)$}

For radiocarbon dating a sufficient amount of planktic foraminifera (G. bulloides and/or Neogloboquadrina pachyderma sinistral) was picked from the $150-250 \mu \mathrm{m}$ size fraction. Radiocarbon dating (AMS ${ }^{14} \mathrm{C}$ ) was done by BETA Analytics London, the National Ocean Science Accelerator Mass Spectrometry Facility (NOSAMS) at Woods Hole Oceanographic Institute (WHOI) as well as the LeibnizLaboratory for Radiometric Dating and Isotope Research at Kiel University. Radiocarbon ages are given according to the convention outlined by Stuiver and Polach (1977) and Stuiver (1980) and summarized in Table 2. We applied reservoir age correction of $+900 \mathrm{yr}$ (Max et al., 2012) for core SO178-13-6, which is determined by a marine global average reservoir age correction of $+400 \mathrm{yr}$ (Reimer et al., $2013)$ and a local planktic reservoir age correction $(\Delta R)$ of $+500 \mathrm{yr}$ reported for the Okhotsk Sea environment (Kuzmin et al., 2001, 2007). There is increasing evidence that surface reservoir ages could have varied over the course of the last $20 \mathrm{kyr}$, due to global thermohaline reorganizations as well as changes in upper-ocean stratification. In the northeast $\mathrm{Pa}$ cific, surface ocean reservoir ages have been reported to be close to $730 \pm 200 \mathrm{yr}$ and varied by less than $200 \mathrm{yr}$ during the last deglaciation (Lund et al., 2011). A recent study based on plateau tuning shows that northwest Pacific reservoir ages varied by a few hundred years during the last glacial termination (Sarnthein et al., 2013). Since available ${ }^{14} \mathrm{C}$ datings are by far not dense enough to identify the age-calibrated ${ }^{14} \mathrm{C}$-plateaus in sediment cores presented here, we were not able to assess the variability of paleo-reservoir ages. However, the reservoir age corrections used in this study are well within the range of calculated reservoir age changes reported from plateau tuning during the last deglaciation but the use of constant reservoir ages inevitably leads to an uncertainty of a few hundred years in the calculated age models and intermediate- to deep-water ventilation ages. All planktic radiocarbon ages were converted into calibrated 1-sigma calendar age ranges using the calibration tool Calib 7.0 (Stuiver and Reimer, 1993) with the Intcal13 atmospheric calibration curve (Reimer et al., 2013). In addition to planktic ${ }^{14} \mathrm{C}$ measurements radiocarbon dating was performed on monospecific samples of the benthic foraminifera Uvigerina peregrina or, in some intervals with low abundance, mixed benthics to assess past changes in ventilation ages. Ventilation ages were calculated from raw ${ }^{14} \mathrm{C}$ age differences between coeval planktic and benthic foraminifers (Broecker et al., 2004). In total, 26 ventilation ages were derived from a set of seven sediment cores covering a depth range of $\sim 600$ $2100 \mathrm{~m}$ water depth in the northwest Pacific region (Fig. 1 and Table 2). These data, together with published ventilation ages from the deep northwest Pacific ( $>2100 \mathrm{~m}$ water depth), are summarized in Table 3.

\section{Chronology}

The stratigraphy of the sediment records from the Bering Sea (SO201-2-77KL; SO201-1-85KL; SO201-2-101KL), Okhotsk Sea (LV29-114-3) and the northwest Pacific (SO201-2-12KL) (Fig. 1) is presented in detail in Max et al. (2012). These records are part of a stratigraphic framework for the subarctic northwest Pacific and its marginal seas (Riethdorf et al., 2013). In general, it is based on detailed core-to-core correlations using high-resolution XRF measurements and core-logger data, further constrained by 40 planktic foraminiferal AMS ${ }^{14} \mathrm{C}$ datings spanning the time interval of the last deglaciation. For this study, core SO178-13-6 from the Okhotsk Sea $\left(52^{\circ} 43^{\prime} \mathrm{N}, 144^{\circ} 42^{\prime} \mathrm{E}\right.$; $713 \mathrm{~m}$ water depth) was integrated via correlation of $\mathrm{Ca}$ intensity records (based on XRF-scanning) and AMS ${ }^{14} \mathrm{C}$ datings to the established stratigraphic framework for the subarctic northwest Pacific and its marginal seas as shown in Fig. 2 (Max et al., 2012).

\section{Results and discussion}

\subsection{Modern properties of Okhotsk Sea and Bering Sea $\delta^{13} \mathrm{C}_{\text {DIC }}$}

The modern distribution of $\delta^{13} \mathrm{C}_{\mathrm{DIC}}$ in the water column indicates large differences between the Okhotsk Sea and Bering Sea as shown in Fig. 3. As expected, the $\delta^{13} \mathrm{C}_{\text {DIC }}$ profile from the Okhotsk Sea shows a smooth decline of $\delta^{13} C_{\text {DIC }}$ values within the water column between $200-800 \mathrm{~m}$ water depth (Fig. 3). This marks the presence of fresh, newly formed Okhotsk Sea Intermediate Water (OSIW), which spreads across the Okhotsk Sea, subsequently exported through the Kurile Straits into the northwest Pacific. Today, the Okhotsk Sea core site SO178-13-6 is bathed in OSIW with $\delta^{13} \mathrm{C}_{\text {DIC }}$ values around $-0.3 \%$.

In the western Bering Sea, a large gradient in $\delta^{13} \mathrm{C}_{\mathrm{DIC}}$ exists around $150 \mathrm{~m}$ water depth, which marks the maximum in mixed layer depth of surface water mixing with underlying water masses during winter (Fig. 3). Beyond this depth, the $\delta^{13} \mathrm{C}_{\mathrm{DIC}}$ values rapidly decline to -0.6 to $-0.7 \%$ and indicate nutrient-rich, poorly ventilated water masses in the western Bering Sea today. Low $\delta^{13} \mathrm{C}_{\text {DIC }}$ values of $\sim-0.6 \%$ o mark the depth interval of sediment core SO201-2-85KL and are related to the intrusion of old and 


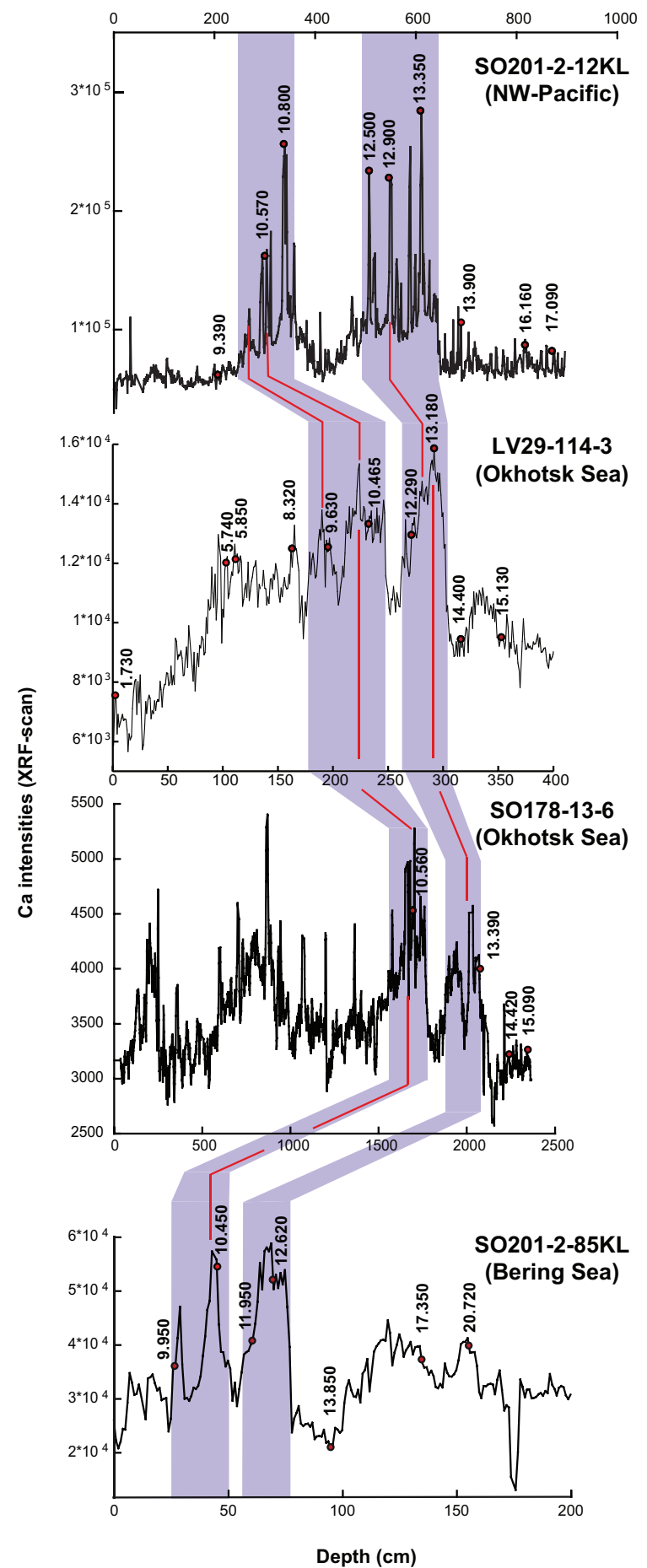

Fig. 2. Stratigraphic framework of sediment records from the western Bering Sea (SO201-2-85KL) and Okhotsk Sea (SO178-13-6). Red lines indicate correlation points to the established stratigraphy of Okhotsk Sea record LV29-114-3 and high-resolution sediment core SO201-2-12KL from the subarctic northwest Pacific (Max et al., 2012). Given are the Ca-intensity records achieved from core logging (XRF) together with raw AMS ${ }^{14} \mathrm{C}$ datings (red spots with vertical numbers). Purple shaded areas mark prominent carbonate maxima in the sediment records during the Bølling/Allerød and early Holocene.

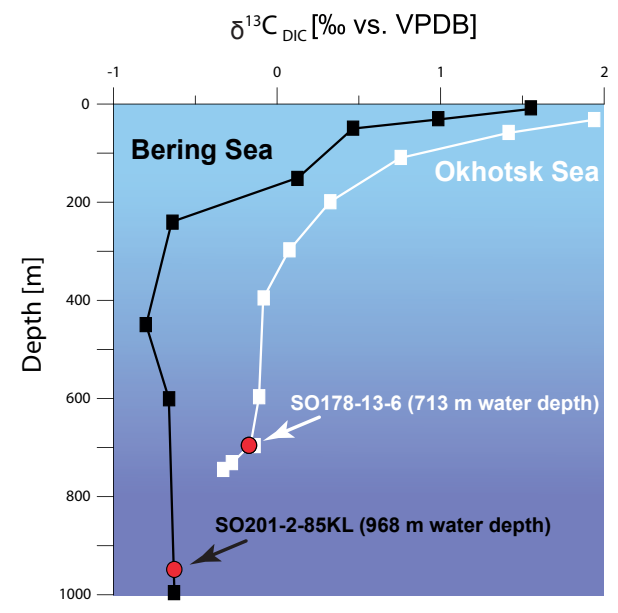

Fig. 3. Water column profiles of $\delta^{13} \mathrm{C}_{\text {DIC }}$ in the Bering Sea (station SO201-2-67) and Okhotsk Sea (station LV29-84-3). Black curve with squares indicating sampled depth intervals given as $\delta^{13} \mathrm{C}_{\mathrm{DIC}}$ profile of the Bering Sea together with the respective depth-interval of SO201-2-85KL (red spot). White curve with squares indicating sampled depth intervals of $\delta^{13} \mathrm{C}_{\text {DIC }}$ profile for the Okhotsk Sea together with the corresponding depth-interval of SO178-13-6 (red spot).

nutrient-rich Pacific deep water at this site (Luchin et al., 1999).

\subsection{Characteristics of deglacial NPIW variations and their potential source regions}

We use the down-core variations in $\delta^{13} \mathrm{C}$ and ventilation ages to assess the timing and magnitude of paleo-circulation changes in the subarctic northwest Pacific and its marginal seas. To infer the relative timing of circulation changes in the western Bering Sea we compare the intermediate-depth benthic $\delta^{13} \mathrm{C}$ record to published ${ }^{231} \mathrm{~Pa} /{ }^{230} \mathrm{Th}$ data (proposed to reflect the strength of the AMOC) from the North Atlantic (McManus et al., 2004) and millennial-scale climate oscillations of Greenland (Rasmussen et al., 2006) during the last deglaciation (Fig. 4). In general, the western Bering Sea $\delta^{13} \mathrm{C}$ proxy data reveals millennial-scale, rapid oscillations in $\delta^{13} \mathrm{C}$ that indicate repeated intermediate-depth changes in nutrient and oxygen level and associated changes in circulation. These prominent, short-term excursions in $\delta^{13} \mathrm{C}$ are strictly opposite in sign (ventilation seesaw) compared to the North Atlantic deep circulation history of the last $20 \mathrm{kyr}$ as indicated by ${ }^{231} \mathrm{~Pa} /{ }^{230} \mathrm{Th}$ data (Fig. 4).

Specifically, the western Bering Sea $\delta^{13} \mathrm{C}$ proxy data point to times of nutrient-depleted and well-ventilated intermediate water during HS-1 (17.5-15 ka BP) and the YD $(12.8-11.8 \mathrm{ka} \mathrm{BP})$ as indicated by relatively high $\delta^{13} \mathrm{C}$ values $(-0.1$ to $-0.2 \%$ ) during times when North Atlantic Deep Water (NADW) formation in the North Atlantic was significantly reduced (McManus et al., 2004). Compared to 
Table 2. AMS ${ }^{14} \mathrm{C}$ ages of the sediment records with calibrated calendar ages $\pm 1 \sigma$ (yr) and applied reservoir age correction used in this study.

\begin{tabular}{|c|c|c|c|c|c|c|}
\hline $\begin{array}{l}\text { Laboratory } \\
\text { number }\end{array}$ & Sediment core & $\begin{array}{l}\text { Core } \\
\text { depth } \\
(\mathrm{cm})\end{array}$ & Species & $\begin{array}{l}\text { Conventional } \\
\text { radiocarbon } \\
\text { age }(\mathrm{yr})\end{array}$ & $\begin{array}{l}\text { Calendar age } \\
\quad \pm 1 \sigma(\mathrm{yr})\end{array}$ & $\begin{array}{c}\text { Reservoir } \\
\text { age } \\
(\mathrm{yr})\end{array}$ \\
\hline OS-85655* & SO201-2-12KL & $210-211$ & N. pachyderma sin. & $9390 \pm 40$ & 9484-9527 & 900 \\
\hline KIA44680* & $\left(53^{\circ} 59^{\prime} \mathrm{N}, 162^{\circ} 22^{\prime} \mathrm{E}\right)$ & $295-296$ & N. pachyderma sin. & $10570 \pm 50$ & $11080-11191$ & 900 \\
\hline OS-87895* & & $340-341$ & N. pachyderma sin. & $10800 \pm 65$ & $11231-11368$ & 900 \\
\hline OS-88040 & & $340-341$ & Uvigerina peregrina & $11750 \pm 50$ & - & - \\
\hline OS-92047* & & $508-509$ & N. pachyderma sin. & $12500 \pm 50$ & $13371-13480$ & 900 \\
\hline OS-92050 & & $508-509$ & Uvigerina peregrina & $13500 \pm 55$ & - & - \\
\hline OS-87891* & & $550-551$ & N. pachyderma sin. & $12900 \pm 50$ & $13764-13927$ & 900 \\
\hline OS-87880 & & $550-551$ & Uvigerina peregrina & $13850 \pm 50$ & - & - \\
\hline OS-87902* & & $610-611$ & N. pachyderma sin. & $13350 \pm 65$ & $14328-14776$ & 900 \\
\hline OS-92150* & & $695-696$ & N. pachyderma sin. & $13900 \pm 55$ & $15422-15685$ & 900 \\
\hline OS-104953 & & $695-696$ & Uvigerina peregrina & $15300 \pm 95$ & - & - \\
\hline KIA44682* & & $820-821$ & N. pachyderma sin. & $16160 \pm 80$ & $18431-18631$ & 900 \\
\hline KIA44683* & & $875-876$ & N. pachyderma sin. & $17090 \pm 90$ & $19406-19672$ & 900 \\
\hline OS-104797 & LV29-114-3 & 7-8 & N. pachyderma sin. & $1730 \pm 35$ & $697-764$ & 900 \\
\hline OS-104961 & $\left(49^{\circ} 22^{\prime} \mathrm{N}, 152^{\circ} 53^{\prime} \mathrm{E}\right)$ & $102-103$ & N. pachyderma sin. & $5740 \pm 50$ & $5483-5642$ & 900 \\
\hline transferred age* & & $108-109$ & N. pachyderma sin. & $5850 \pm 60$ & $5608-5729$ & 900 \\
\hline OS- $88042^{*}$ & & $162-163$ & N. pachyderma sin. & $8320 \pm 40$ & $8236-8309$ & 900 \\
\hline KIA30864* & & $197-198$ & N. pachyderma sin. & $9630 \pm 50$ & $9563-9768$ & 900 \\
\hline OS-104963 & & $197-198$ & Uvigerina peregrina & $10450 \pm 70$ & - & - \\
\hline KIA30863* & & $232-233$ & N. pachyderma sin. & $10465 \pm 50$ & $10763-11074$ & 900 \\
\hline OS-104964 & & $232-233$ & Uvigerina peregrina & $11200 \pm 75$ & - & - \\
\hline KIA30867* & & $272-273$ & N. pachyderma sin. & $12290 \pm 55$ & $13165-13285$ & 900 \\
\hline OS-104796 & & $272-273$ & Uvigerina peregrina & $12900 \pm 85$ & - & - \\
\hline KIA30865* & & $292-293$ & N. pachyderma sin. & $13180 \pm 60$ & $14072-14315$ & 900 \\
\hline OS-104965 & & $292-293$ & Uvigerina peregrina & $14000 \pm 95$ & - & - \\
\hline KIA30868* & & $317-318$ & N. pachyderma sin. & $14400 \pm 80$ & $16113-16373$ & 900 \\
\hline OS-105415 & & $317-318$ & Uvigerina peregrina & $14750 \pm 130$ & - & - \\
\hline KIA30866* & & $352-353$ & N. pachyderma sin. & $15130 \pm 80$ & $17198-17460$ & 900 \\
\hline OS-104966 & & $352-353$ & Uvigerina peregrina & $16600 \pm 120$ & - & - \\
\hline KIA30872 & SO178-13-6 & $1682-1683$ & N. pachyderma sin. & $10560 \pm 50$ & $10874-11183$ & 900 \\
\hline KIA30869 & $\left(52^{\circ} 43^{\prime} \mathrm{N}, 144^{\circ} 42^{\prime} \mathrm{E}\right)$ & 2072-2073 & N. pachyderma sin. & $13390 \pm 100$ & $14422-14975$ & 900 \\
\hline Beta-324995 & & 2072-2073 & mixed benthos & $13760 \pm 60$ & - & - \\
\hline UCIAMS109675 & & $2250-2251$ & N. pachyderma sin. & $14420 \pm 45$ & $16176-16361$ & 900 \\
\hline Beta-324996 & & $2250-2251$ & mixed benthos & $14580 \pm 60$ & - & - \\
\hline UCIAMS109674 & & $2342-2343$ & N. pachyderma sin. & $15090 \pm 60$ & $17166-17396$ & 900 \\
\hline Beta-324997 & & $2342-2343$ & mixed benthos & $15470 \pm 60$ & - & - \\
\hline OS-85658* & SO201-2-77KL & 115-116 & N. pachyderma sin. & $10450 \pm 40$ & $11174-11222$ & 700 \\
\hline OS-85660 & $\left(56^{\circ} 19^{\prime} \mathrm{N}, 170^{\circ} 41^{\prime} \mathrm{E}\right)$ & $115-116$ & Uvigerina peregrina & $11650 \pm 45$ & - & - \\
\hline OS-90700* & & $155-156$ & N. pachyderma sin. & $11500 \pm 50$ & $12688-12734$ & 700 \\
\hline OS-104954 & & $155-156$ & Uvigerina peregrina & $13000 \pm 70$ & - & - \\
\hline OS-85664* & & $180-181$ & N. pachyderma sin. & $13200 \pm 45$ & $14569-14958$ & 700 \\
\hline OS-85670 & & $180-181$ & Uvigerina peregrina & $14450 \pm 85$ & - & - \\
\hline OS- $85665^{*}$ & SO201-2-85KL & $26-27$ & N. pachyderma sin. & $9950 \pm 40$ & $10300-10507$ & 700 \\
\hline OS-104759 & $\left(57^{\circ} 30^{\prime} \mathrm{N}, 170^{\circ} 24^{\prime} \mathrm{E}\right)$ & $43-44$ & N. pachyderma sin. & $10450 \pm 55$ & $11152-11234$ & 700 \\
\hline OS-105429 & & $43-44$ & Uvigerina peregrina & $11250 \pm 110$ & - & - \\
\hline OS-85669* & & $60-61$ & N. pachyderma sin. & $11950 \pm 45$ & $13069-13141$ & 700 \\
\hline KIA42232* & & $70-71$ & N. pachyderma sin. & $12620 \pm 90$ & $13583-13834$ & 700 \\
\hline OS-104959 & & $93-94$ & N. pachyderma sin. & $13850 \pm 80$ & $15661-15939$ & 700 \\
\hline OS-104757 & & 93-94 & Uvigerina peregrina & $14050 \pm 80$ & - & - \\
\hline OS-87890* & & $135-136$ & N. pachyderma sin. & $17350 \pm 65$ & $19983-20193$ & 700 \\
\hline Beta-325004 & & $135-136$ & mixed benthos & $19210 \pm 90$ & - & - \\
\hline KIA42233* & & $155-156$ & N. pachyderma sin. & $20720 \pm 160$ & $23892-24281$ & 700 \\
\hline OS-87887* & $\begin{array}{l}\text { SO201-2-101KL } \\
\left(58^{\circ} 52^{\prime} \mathrm{N}, 170^{\circ} 41^{\prime} \mathrm{E}\right)\end{array}$ & $10-11$ & N. pachyderma sin. & $12600 \pm 55$ & $13609-13774$ & 700 \\
\hline
\end{tabular}


Table 2. Continued.

\begin{tabular}{|c|c|c|c|c|c|c|}
\hline $\begin{array}{l}\text { Laboratory } \\
\text { number }\end{array}$ & Sediment core & $\begin{array}{l}\text { Core } \\
\text { depth } \\
(\mathrm{cm})\end{array}$ & Species & $\begin{array}{l}\text { Conventional } \\
\text { radiocarbon } \\
\text { age }(\mathrm{yr})\end{array}$ & $\begin{array}{l}\text { Calendar age } \\
\quad \pm 1 \sigma(\mathrm{yr})\end{array}$ & $\begin{array}{c}\text { Reservoir } \\
\text { age } \\
(\mathrm{yr})\end{array}$ \\
\hline OS-104795 & & $10-11$ & Uvigerina peregrina & $12850 \pm 95$ & - & - \\
\hline OS-88041* & & $90-91$ & N. pachyderma sin. & $14950 \pm 60$ & $17243-17470$ & 700 \\
\hline OS-104960 & & $90-91$ & Uvigerina peregrina & $16800 \pm 130$ & - & - \\
\hline KIA42229 & & $110-111$ & N. pachyderma sin. & $17310 \pm 120$ & $19875-20211$ & 700 \\
\hline KIA43068* & & $110-111$ & Uvigerina peregrina & $18630 \pm 200$ & - & - \\
\hline OS-85756 & SO202-18-6 & $415-417.5$ & N. pachyderma sin. & $10850 \pm 25$ & $11754-11835$ & 700 \\
\hline OS-90698 & $\left(60^{\circ} 07^{\prime} \mathrm{N}, 179^{\circ} 26^{\prime} \mathrm{W}\right)$ & $415-417.5$ & mixed benthos & $11300 \pm 50$ & - & - \\
\hline OS-96111 & & $432-434.5$ & N. pachyderma sin. & $10950 \pm 55$ & $11829-12100$ & 700 \\
\hline OS-96112 & & $432-434.5$ & mixed benthos & $11550 \pm 60$ & - & - \\
\hline OS-94120 & & $512-514.5$ & N. pachyderma sin. & $11150 \pm 65$ & $12235-12528$ & 700 \\
\hline OS-96034 & & $512-514.5$ & mixed benthos & $11800 \pm 60$ & - & - \\
\hline OS-96095 & & $592-594.5$ & N. pachyderma sin. & $11850 \pm 60$ & $12963-13094$ & 700 \\
\hline OS-96035 & & $592-594.5$ & mixed benthos & $12300 \pm 80$ & - & - \\
\hline
\end{tabular}

${ }^{*}$ AMS ${ }^{14} \mathrm{C}$ ages derived from Max et al. (2012).

modern conditions (see also Sect. 4.1) $\delta^{13} \mathrm{C}$ values increase by $\sim 0.4-0.5 \%$ during HS-1 and YD, respectively. However, as soon as the North Atlantic deep overturning cell was re-established during the Bølling/Allerød (14.7-12.8 ka BP) and the onset of the Holocene, nutrient-rich, poorly ventilated western Bering Sea intermediate water approached modern values of $\sim-0.4$ to $-0.7 \%$ and point to rapid changes in ocean circulation (Fig. 4).

The deglacial pattern of Okhotsk Sea changes in intermediate water resembles the intermediate-depth circulation history of the Bering Sea (Fig. 5). Although the timing of changes is similar, the amplitude of changes is significantly higher in the Okhotsk Sea (up to $1.4 \%$ ). Lowest $\delta^{13} \mathrm{C}$ values $(-0.3$ to $-0.7 \%$ ) are recorded during the Bølling/Allerød interstadial (14.7-12.8 ka BP) and the earliest Holocene, similar to the western Bering Sea. However, the $\delta^{13} \mathrm{C}$ maxima with values of up $+0.7 \%$ during HS-1 (17.5-15 ka BP) and of up to $+0.6 \%$ o during the YD (11.8-12.8 ka BP) are significantly higher in the Okhotsk Sea than in the Bering Sea. These values suggest a strong intermediate-depth convection cell proximal to the Okhotsk Sea during deglacial cold stages, in particular during HS-1. These nutrient-depleted and well-ventilated water masses, indicated by $\delta^{13} \mathrm{C}$ maxima, were subsequently exported into the northwest Pacific and were the likely source of enhanced deglacial NPIW (Duplessy et al., 1989; Adkins and Boyle, 1997; Ahagon et al., 2003; Sagawa and Ikehara, 2008), which probably also ventilated the Bering Sea (Rella et al., 2012). In this context, it is important to note that the vertical expansion of these water masses did not reach the deep-water level in the northwest Pacific. This is clearly indicated by the comparison with the $\delta^{13} \mathrm{C}$ deep-water record of GGC-37 from $3300 \mathrm{~m}$ water depth (Keigwin, 1998). The deep-water $\delta^{13} \mathrm{C}$ record impressively shows a temporal variability that is opposite

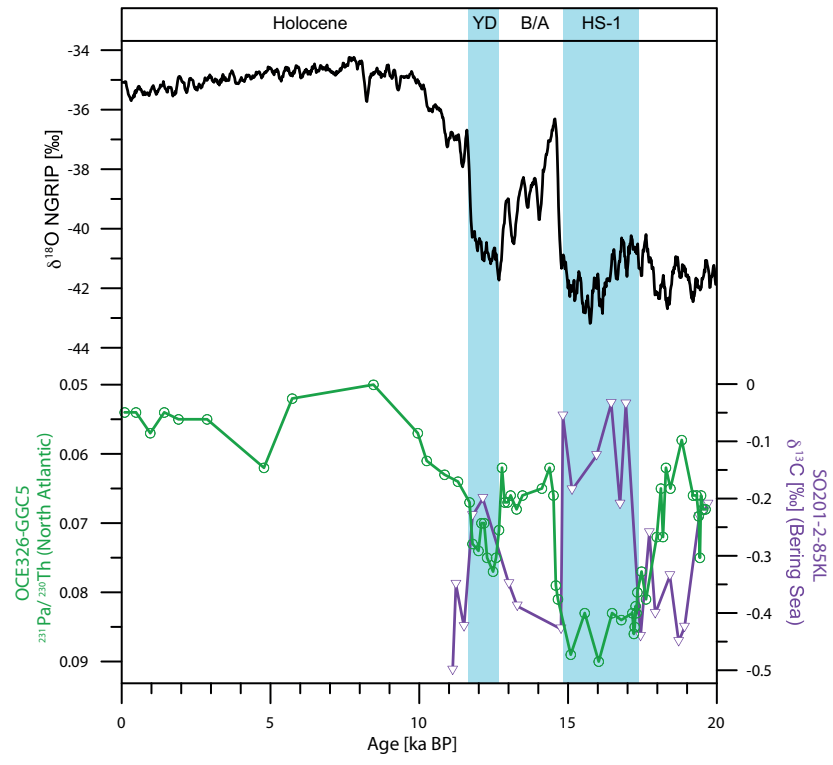

Fig. 4. Detailed comparison of deglacial circulation changes in the North Atlantic and western Bering Sea during the past $20 \mathrm{kyr}$. Given are the $\mathrm{Pa} / \mathrm{Th}$ ratio as proxy for the AMOC strength in the North Atlantic (in green) (McManus et al., 2004) compared to the western Bering Sea intermediate-depth $\delta^{13} \mathrm{C}$ record (in purple) as proxy for circulation changes in the North Pacific. Blue shaded areas mark stadial HS-1 and the YD. For comparison, the NGRIP ice core record (in black) is given on top (Rasmussen et al., 2006).

to the intermediate-water level with minima during HS-1 $(-0.6 \%$ ) and the YD $(-0.3 \%$ ) and thus characterizes another water mass (Fig. 5). Furthermore, the deep-water $\delta^{13} \mathrm{C}$ signal reach maxima during the Bølling/Allerød $(-0.1 \%$ ) and early Holocene $(+0.1 \%$ ) and its characteristics are different from those of intermediate-water depths derived from 


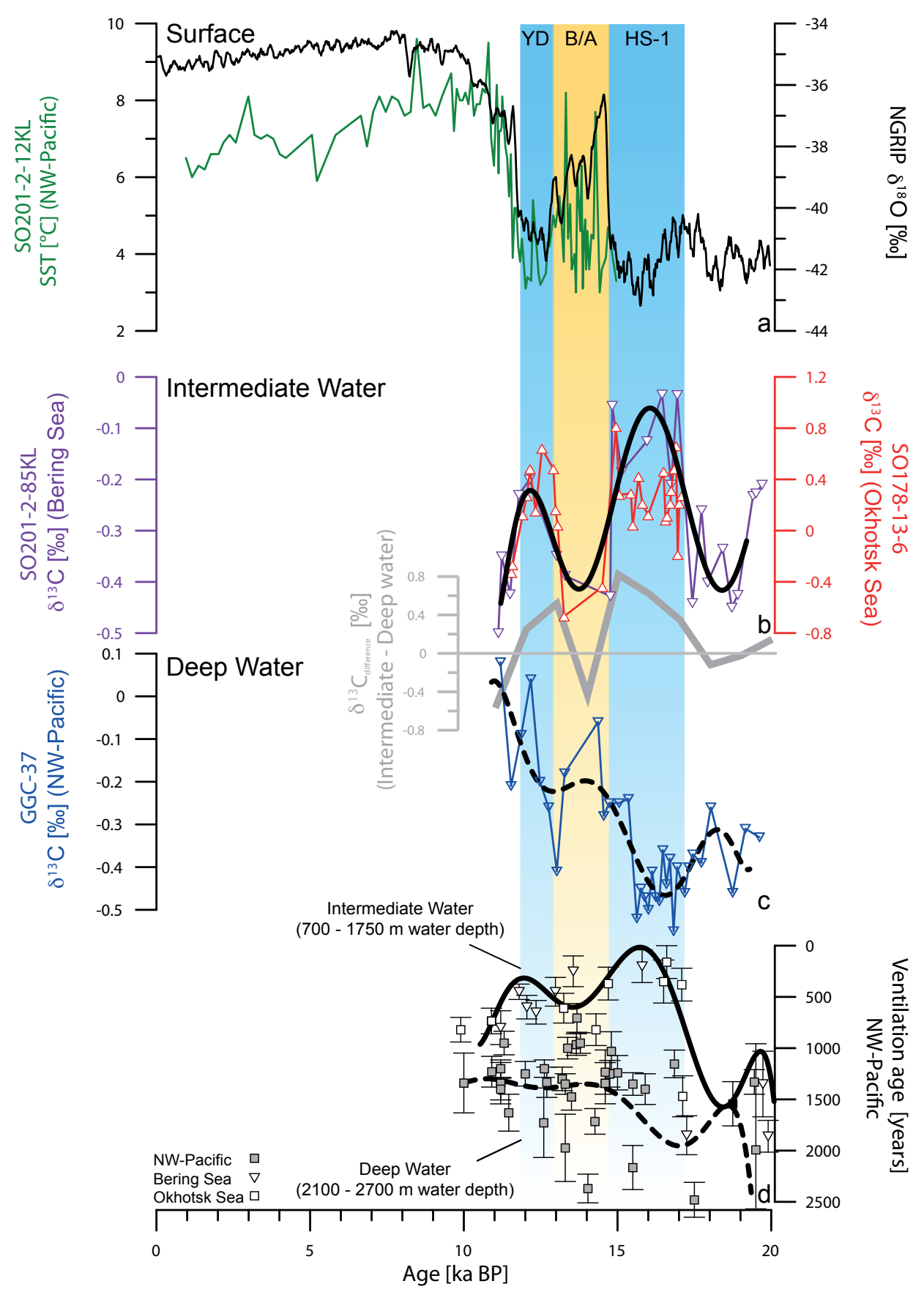

Fig. 5. Sediment proxy records of changes in surface-, intermediate- and deep-water properties in the northwest Pacific realm during the past 20 kyr. Blue and yellow shaded bars mark HS-1 and YD as well as the Bølling/Allerød interstadial. From top to bottom (a) alkenonebased sea surface temperature record of sediment record SO201-2-12KL (in green) from the northwest Pacific (Max et al., 2012) for the last $15 \mathrm{kyr}$ together with NGRIP oxygen isotope record in black (Rasmussen et al., 2006). (b) Benthic foraminiferal $\delta^{13} \mathrm{C}$-records $(C$. lobatulus) from the Okhotsk Sea $(\sim 700 \mathrm{~m}$ water depth; red curve $)$ and Bering Sea $(\sim 1000 \mathrm{~m}$ water depth; purple curve $)$ together with smoothed spline interpolation of the records (thick black line). (c) Benthic $\delta^{13} \mathrm{C}$-record from sediment record GGC-37 (Keigwin, 1998) from the deep northwest Pacific ( $\sim 3300 \mathrm{~m}$ water depth, blue curve) and smoothed spline interpolation of the record (stippled black line). Thick gray line gives difference between intermediate- to deep-water $\delta^{13} \mathrm{C}$ records. (d) Okhotsk Sea and Bering Sea intermediate-water ventilation ages obtained in this study (700-1750 m water depth; open squares and triangles) compared to deep-water ventilation ages (2100-2700 $\mathrm{m}$ water depth; gray squares) of the northwest Pacific (Murayama et al., 1992; Sarnthein et al., 2006; Minoshima et al., 2007; Okazaki et al., 2012; this study). Calculated error bars are given for each estimated ventilation age. Smoothed spline interpolations for intermediate- and deep-water ventilation ages are given by the thick black line (intermediate water) and thick stippled black line (deep water), respectively. 
Table 3. Radiocarbon measurements on coeval benthic/planktic foraminiferas (ventilation ages) from NW-Pacific sediment cores. Ventilation ages are given in years and era is indicated by LGM, HS-1, YD, B/A and Holocene.

\begin{tabular}{|c|c|c|c|c|c|c|c|c|c|}
\hline Core & $\begin{array}{c}\text { Water } \\
\text { depth } \\
(\mathrm{m})\end{array}$ & $\begin{array}{c}\text { Core } \\
\text { depth } \\
(\mathrm{cm})\end{array}$ & $\begin{array}{c}\text { Planktic } \\
{ }^{14} \mathrm{C} \text {-age }(\mathrm{yr})\end{array}$ & $\begin{array}{c}\text { Benthic } \\
{ }^{14} \mathrm{C} \text {-age }(\mathrm{yr})\end{array}$ & $\begin{array}{c}\text { Calendar } \\
\text { age } \\
(\mathrm{kaBP})^{*}\end{array}$ & $\begin{array}{c}\text { Ventilation } \\
\text { age } \\
\text { (yr) }\end{array}$ & $\begin{array}{c}\text { Error } \\
\pm 1 \text {-Sigma } \\
\quad(\mathrm{yr})\end{array}$ & Era & Reference \\
\hline \multicolumn{10}{|c|}{ Bering Sea (intermediate) } \\
\hline SO201-2-101KL & 630 & 10 & $12600 \pm 55$ & $12850 \pm 95$ & 13.60 & 250 & 150 & $\mathrm{~B} / \mathrm{A}$ & this study \\
\hline SO201-2-101KL & 630 & 90 & $14950 \pm 60$ & $16800 \pm 130$ & 17.25 & 1850 & 190 & HS-1 & \\
\hline SO201-2-101KL & 630 & 110 & $17310 \pm 120$ & $18630 \pm 200$ & 19.90 & 1320 & 320 & LGM & \\
\hline SO201-2-85KL & 968 & 43 & $10450 \pm 55$ & $11250 \pm 110$ & 11.20 & 800 & 165 & Holocene & this study \\
\hline SO201-2-85KL & 968 & 93 & $13850 \pm 80$ & $14050 \pm 80$ & 15.80 & 200 & 160 & HS-1 & \\
\hline SO201-2-85KL & 968 & 135 & $17350 \pm 65$ & $19210 \pm 90$ & 19.90 & 1860 & 155 & LGM & \\
\hline SO202-18-6 & 1100 & $415-417.5$ & $10850 \pm 25$ & $11300 \pm 50$ & 11.80 & 450 & 75 & YD & this study \\
\hline SO202-18-6 & 1100 & $432-434.5$ & $10950 \pm 55$ & $11550 \pm 60$ & 12.05 & 600 & 115 & YD & \\
\hline SO202-18-6 & 1100 & $512-514.5$ & $11150 \pm 65$ & $11800 \pm 60$ & 12.35 & 650 & 115 & YD & \\
\hline SO202-18-6 & 1100 & $592-594.5$ & $11850 \pm 60$ & $12300 \pm 80$ & 12.98 & 450 & 140 & YD & \\
\hline \multicolumn{10}{|c|}{ Okhotsk Sea (intermediate) } \\
\hline SO178-13-6 & 713 & 2072.5 & $13390 \pm 100$ & $13760 \pm 60$ & 14.70 & 370 & 160 & $\mathrm{~B} / \mathrm{A}$ & this study \\
\hline SO178-13-6 & 713 & 2250.5 & $14420 \pm 45$ & $14580 \pm 60$ & 16.30 & 160 & 160 & HS-1 & \\
\hline SO178-13-6 & 713 & 2342.5 & $15090 \pm 60$ & $15470 \pm 60$ & 17.20 & 380 & 160 & HS-1 & \\
\hline LV29-114-3 & 1765 & 197 & $9630 \pm 50$ & $10450 \pm 70$ & 9.60 & 820 & 120 & Holocene & this study \\
\hline LV29-114-3 & 1765 & 232 & $10465 \pm 50$ & $11200 \pm 75$ & 10.90 & 735 & 125 & Holocene & \\
\hline LV29-114-3 & 1765 & 272 & $12290 \pm 55$ & $12900 \pm 85$ & 13.25 & 610 & 145 & $\mathrm{~B} / \mathrm{A}$ & \\
\hline LV29-114-3 & 1765 & 292 & $13180 \pm 60$ & $14000 \pm 95$ & 14.30 & 820 & 155 & $\mathrm{~B} / \mathrm{A}$ & \\
\hline LV29-114-3 & 1765 & 317 & $14400 \pm 80$ & $14750 \pm 130$ & 16.30 & 350 & 210 & HS-1 & \\
\hline LV29-114-3 & 1765 & 352 & $15130 \pm 80$ & $16600 \pm 120$ & 17.20 & 1470 & 200 & HS-1 & \\
\hline \multicolumn{10}{|c|}{ North Pacific (deep) } \\
\hline SO201-2-12KL & 2145 & 340 & $10800 \pm 65$ & $11750 \pm 50$ & 11.31 & 950 & 115 & Holocene & this study \\
\hline SO201-2-12KL & 2145 & 508 & $12500 \pm 50$ & $13500 \pm 55$ & 13.38 & 1000 & 105 & $\mathrm{~B} / \mathrm{A}$ & \\
\hline SO201-2-12KL & 2145 & 550 & $12900 \pm 50$ & $13850 \pm 50$ & 13.79 & 950 & 100 & $\mathrm{~B} / \mathrm{A}$ & \\
\hline SO201-2-12KL & 2145 & 695 & $13900 \pm 55$ & $15300 \pm 95$ & 15.60 & 1400 & 150 & HS-1 & \\
\hline KR02-15 PC6 & 2215 & 539.2 & $10610 \pm 90$ & $11840 \pm 60$ & 10.91 & 1230 & 150 & Holocene & Minoshima et al. (2007) \\
\hline KR02-15 PC6 & 2215 & 555.1 & $10860 \pm 70$ & $12490 \pm 110$ & 11.46 & 1630 & 180 & Holocene & \\
\hline KR02-15 PC6 & 2215 & 575.6 & $13470 \pm 70$ & $14500 \pm 120$ & 14.80 & 1030 & 190 & $\mathrm{~B} / \mathrm{A}$ & \\
\hline KT89-18-P4 & 2700 & $185-190$ & $9800 \pm 133$ & $11140 \pm 159$ & 10.00 & 1340 & 292 & Holocene & Murayama et al. (1992) \\
\hline KT89-18-P4 & 2700 & 200-204 & $10692 \pm 108$ & $12034 \pm 94$ & 11.20 & 1342 & 202 & Holocene & \\
\hline KT89-18-P4 & 2700 & $236-240$ & $11622 \pm 101$ & $13350 \pm 238$ & 12.60 & 1728 & 339 & YD & \\
\hline KT89-18-P4 & 2700 & $268-272$ & $12450 \pm 91$ & $14423 \pm 237$ & 13.30 & 1973 & 328 & $\mathrm{~B} / \mathrm{A}$ & \\
\hline KT89-18-P4 & 2700 & $338-342$ & $13447 \pm 113$ & $14681 \pm 103$ & 14.60 & 1234 & 216 & $\mathrm{~B} / \mathrm{A}$ & \\
\hline KT89-18-P4 & 2700 & $449-453$ & $17275 \pm 478$ & $19267 \pm 557$ & 19.50 & 1992 & 1035 & LGM & \\
\hline KT89-18-P4 & 2700 & $534-538$ & $19655 \pm 303$ & $21344 \pm 205$ & 22.50 & 1689 & 508 & LGM & \\
\hline MD01-2416 & 2317 & 88 & $12690 \pm 50$ & $13655 \pm 55$ & 13.66 & 965 & 105 & $\mathrm{~B} / \mathrm{A}$ & Sarnthein et al. (2006) \\
\hline MD01-2416 & 2317 & 96 & $12555 \pm 60$ & $14030 \pm 70$ & 13.50 & 1475 & 130 & $\mathrm{~B} / \mathrm{A}$ & \\
\hline MD01-2416 & 2317 & 115 & $13205 \pm 55$ & $14920 \pm 70$ & 14.27 & 1715 & 125 & $\mathrm{~B} / \mathrm{A}$ & \\
\hline MD01-2416 & 2317 & 136 & $13090 \pm 60$ & $15460 \pm 80$ & 14.04 & 2370 & 140 & $\mathrm{~B} / \mathrm{A}$ & \\
\hline MD01-2416 & 2317 & 140.5 & $13795 \pm 60$ & $15960 \pm 100$ & 15.50 & 2165 & 215 & HS-1 & \\
\hline MD01-2416 & 2317 & 177 & $15380 \pm 70$ & $17860 \pm 100$ & 17.50 & 2480 & 170 & HS-1 & \\
\hline ODP883 & 2385 & 51 & $12715 \pm 50$ & $13420 \pm 90$ & 13.68 & 705 & 140 & $\mathrm{~B} / \mathrm{A}$ & \\
\hline MD01-2420 & 2101 & $339.2-344.1$ & $10700 \pm 55$ & $12100 \pm 50$ & 11.20 & 1400 & 105 & Holocene & Okazaki et al. (2012) \\
\hline MD01-2420 & 2101 & $353.8-358.6$ & $11150 \pm 55$ & $12400 \pm 65$ & 12.00 & 1250 & 120 & YD & \\
\hline MD01-2420 & 2101 & $370.7-375.6$ & $11717 \pm 88$ & $13050 \pm 60$ & 12.70 & 1333 & 148 & YD & \\
\hline MD01-2420 & 2101 & $382.9-385.3$ & $12150 \pm 50$ & $13450 \pm 65$ & 13.00 & 1300 & 115 & $\mathrm{~B} / \mathrm{A}$ & \\
\hline MD01-2420 & 2101 & $390.1-392.6$ & $12400 \pm 45$ & $13750 \pm 55$ & 13.30 & 1350 & 100 & $\mathrm{~B} / \mathrm{A}$ & \\
\hline MD01-2420 & 2101 & $404.7-407.1$ & $13258 \pm 141$ & $14600 \pm 60$ & 14.60 & 1342 & 201 & $\mathrm{~B} / \mathrm{A}$ & \\
\hline MD01-2420 & 2101 & $419.2-421.6$ & $13510 \pm 113$ & $14750 \pm 55$ & 15.00 & 1240 & 168 & HS-1 & \\
\hline MD01-2420 & 2101 & $431.3-433.7$ & $13900 \pm 50$ & $15250 \pm 60$ & 15.50 & 1350 & 110 & HS-1 & \\
\hline MD01-2420 & 2101 & $451.6-454.1$ & $14696 \pm 70$ & $15850 \pm 65$ & 16.80 & 1154 & 135 & HS-1 & \\
\hline MD01-2420 & 2101 & $489.2-494.2$ & $16457 \pm 141$ & $18000 \pm 75$ & 18.75 & 1543 & 216 & & \\
\hline MD01-2420 & 2101 & $504.1-506.6$ & $17020 \pm 50$ & $18350 \pm 70$ & 19.45 & 1330 & 120 & LGM & \\
\hline \multicolumn{10}{|c|}{ Bering Sea (deep) } \\
\hline SO201-2-77KL & 2135 & 115 & $10450 \pm 40$ & $11650 \pm 45$ & 11.20 & 1200 & 85 & Holocene & this study \\
\hline SO201-2-77KL & 2135 & 155 & $11500 \pm 50$ & $13000 \pm 70$ & 12.62 & 1500 & 85 & YD & \\
\hline SO201-2-77KL & 2135 & 180 & $13200 \pm 45$ & $14450 \pm 85$ & 14.75 & 1250 & 130 & $\mathrm{~B} / \mathrm{A}$ & \\
\hline
\end{tabular}

* Radiocarbon ages of planktic foraminifera were recalculated with a constant reservoir age correction of $700 \mathrm{yr}$ for the Bering Sea and $900 \mathrm{yr}$ for the NW-Pacific and Okhotsk Sea. 
the Okhotsk and Bering Sea $(-0.4$ to $-0.7 \%$ ). In general, these results argue for significant differences in origin between intermediate- and deep-water masses in the northwest Pacific, where the intermediate-water signal seems to be strictly coupled to the absence or presence of dense-water formation processes in the Okhotsk Sea. This is also in line with recent results derived from a sediment core in the deeper northwest Pacific, which show no sign of improved ventilation during the early deglaciation (Jaccard and Galbraith, 2013).

The deglacial variability in $\delta^{13} \mathrm{C}$, the timing of intermediate-depth circulation changes as well as the opposing pattern between intermediate and deep water is in harmony with changes in ventilation ages from the North Pacific and its marginal seas (Fig. 5). At the intermediate-water layer (700-1750 m water depth), Okhotsk Sea and Bering Sea ventilation ages are low during HS- 1 and $\mathrm{YD}$, thus pointing to the presence of well-ventilated water masses (Fig. 5). In general, this pattern is consistent with ventilation ages from the intermediate-depth northwest Pacific during HS-1 and YD and, like the results from $\delta^{13} \mathrm{C}$, suggests a close relationship to NPIW (Duplessy et al., 1989; Adkins and Boyle, 1997; Ahagon et al., 2003; Sagawa and Ikehara, 2008). However, a more complex picture evolves during the Bølling/Allerød. On the one hand, higher ventilation ages from Okhotsk Sea core LV29-114-3 ( 1750 $\mathrm{m}$ water depth) point to a reduced vertical expansion of freshly formed intermediate water during this time. On the other hand, there is no significant change in ventilation seen from the shallowest records in the Bering Sea (SO201-2-101; $600 \mathrm{~m}$ water depth) or Okhotsk Sea (SO178-13-6; $713 \mathrm{~m}$ water depth) during the onset of the Bølling/Allerød. In contrast to the intermediate-water layer, deep-water ventilation ages are generally high (Murayama et al., 1992; Keigwin, 2002; Sarnthein et al., 2006; Minoshima et al., 2007; Okazaki et al., 2012) and indicate persistent, old water masses in the deep relative to the intermediate water during the last deglaciation. The largest ventilation age difference between the intermediate- and deep-water masses occurs during HS- 1 and matches the results from $\delta^{13} \mathrm{C}$ measurements, which also indicate the largest vertical gradient in $\delta^{13} \mathrm{C}$ between the intermediate- and deep-water masses of the northwest Pacific during HS-1 (Fig. 5). Differences between the intermediate- and deep-water mass signatures are also visible during $\mathrm{YD}$, but are less pronounced. The opposite is the case from $\sim 20-19 \mathrm{ka} \mathrm{BP}$ and during the Bølling/Allerød as ventilation ages from the intermediate- and deep-water masses slightly converge, indicated by increasing ventilation ages at the intermediate-water layer and decreasing deepwater ventilation ages (Fig. 5)

In summary, during times of HS- 1 and the YD the combination of benthic $\delta^{13} \mathrm{C}$ and ventilation ages suggests: (1) an enhanced NPIW formation and better ventilation down to at least $1750 \mathrm{~m}$ water depth (but shallower than $2100 \mathrm{~m}$ water depth), (2) a deglacial source of intermediate-water formation within or close to the Okhotsk Sea as key region for millennial-scale NPIW changes (3) a more isolated deep water that has been located deeper episodically during the last glacial termination, overlain by younger, relatively fresh intermediate-water masses. This circulation is characterized by strongest vertical gradients in benthic $\delta^{13} \mathrm{C}$ and ventilation ages in the water column, thus indicating significant differences in water mass characteristics between intermediateand deep water during HS-1 and YD (Fig. 5). It is also consistent with studies indicating that the deep North Pacific was more isolated from the atmosphere during HS-1 (Lund et al., 2011; Jaccard and Galbraith, 2013; Lund, 2013) and thus did not contribute to the rise in atmospheric $\mathrm{CO}_{2}$ during this interval (Galbraith et al., 2007). However, these results contradict the model-derived hypothesis of a switch to deep-water formation in the northwest Pacific during HS-1 (Okazaki et al., 2010).

\subsection{Implications for formation processes of expanded NPIW during HS-1}

The large change in OSIW $\delta^{13} \mathrm{C}$ values with amplitudes of $1.5 \%$ between HS- 1 and the Bølling/Allerød provide useful information about the boundary conditions of intermediatewater formation in the northwest Pacific and points to the Okhotsk Sea as primary source for millennial-scale ventilation changes. However, it is also clear that conditions must have been substantially different from those of modern OSIW formation. Under present conditions, intermediatewater masses are a blend of surface water and old Pacific deep water, which enters the Okhotsk Sea basin through the deepest sills of the Kurile Islands (mainly through Kruzenshtern Strait, $\sim 1760 \mathrm{~m}$ water depth) (Talley and Roemmich, 1991). Due to the intrusion of old and nutrient-enriched Pacific deep water, modern OSIW is marked by relatively high nutrient concentrations and low $\delta^{13} \mathrm{C}$ values of 0 to $-0.3 \%$ (see also Fig. 3). Changes in SST (thermodynamic effects) and/or reduced biological productivity cannot solely explain the extremely high $\delta^{13} \mathrm{C}$ values during HS-1. Thus, we speculate that the main source of enhanced OSIW during HS-1 and the YD was shifted from old Pacific deep water to relatively young and nutrient-depleted surface water masses, which flowed from the North Pacific into the Okhotsk Sea. This is in line with the presence of young water masses down to about $1750 \mathrm{~m}$ water depth (i.e., Okhotsk Sea core LV29114-3) during HS-1. Once the intensified OSIW formation flushed the Okhotsk Sea up to the deepest sills, the inflow of old and $\delta^{13} \mathrm{C}$-depleted deep-water masses from the deep North Pacific into the Okhotsk Sea basin must have been significantly hampered or even blocked during HS-1 or the YD. 


\subsection{Relation of deglacial NPIW patterns to changes in Meridional Overturning Circulation and atmospheric pressure regimes}

The implication of a strengthened intermediate-depth meridional overturning in the North Pacific in response to AMOC reductions during HS-1 and YD is in agreement with results from GCM simulations and proxy data, which suggest enhanced ventilation of NPIW down to $\sim 2000 \mathrm{~m}$ water depth during these intervals (Chikamoto et al., 2012) while the deep ocean below remained poorly ventilated (Jaccard and Galbraith, 2012). However, our results do not corroborate model simulations that argue for a more fundamental switch to Pacific deep-water formation down to $\sim 3000 \mathrm{~m}$ water depth (Okazaki et al., 2010). In the first case, the largest cooling trend appears during HS-1 in the GCM simulations in the western North Pacific in association with severe cooling of the overlying atmosphere in the Northern Hemisphere and intensification of the Aleutian Low, thus promoting seaice expansion and enhanced intermediate-depth circulation. In the latter case, the establishment of a deep PMOC is physically coupled to a strengthened northeastward upper-ocean transport of saline subtropical water masses via the North Pacific Current, thereby warming the northwest Pacific during HS-1 and YD (Saenko et al., 2004; Krebs and Timmermann, 2007; Okazaki et al., 2010). However, the establishment of PMOC to buffer the decrease in poleward global oceanic heat transport (Okazaki et al., 2010) is not seen in proxy-based SST reconstructions (Harada et al., 2012; Max et al., 2012). SST records in combination with sea-ice reconstructions provide evidence of surface cooling during HS-1 and YD in the northwest Pacific (Fig. 5) and questions the results of the LOVECLIM model simulation (Max et al., 2012). We thus assume that millennial-scale enhancements in NPIW formation during the last deglaciation can be explained by mechanisms that involve intensified processes of dense-water formation in the Okhotsk Sea, which are in turn coupled to more intense OSIW formation under colder conditions during HS1 and YD.

In addition, our results provide clues for future changes in marine biogeochemistry. Past changes in intermediate-depth oxygen concentrations in the northwest Pacific are often related to a substantial weakening of NPIW and its consequences in favoring the expansion of the oxygen minimum zone at the intermediate-water level (Schmittner et al., 2007; Cartapanis et al., 2011). During the Bølling/Allerød and early Holocene, hypoxic conditions marked the oceanic continental margins in the North Pacific, as well as in the Bering Sea and culminated in the formation of laminated sediments in some of those regions (Behl and Kennett, 1996; Cook et al., 2005; Kim et al., 2011). Under modern conditions, the Okhotsk Sea plays a central role as major contributor of fresh intermediate-water masses in the subarctic Pacific, physically coupled to sea-ice formation (Talley and Roemmich, 1991; Warner et al., 1996; Yasuda, 1997). Environmental changes in the Okhotsk Sea due to a rise in the average temperature of Earth's atmosphere in future may tip the scale for strong OSIW reductions and thus could promote the expansion of hypoxic conditions in the North Pacific. This becomes more evident as the Okhotsk Sea modern seasonal sea-ice cover extends as far as $43^{\circ} \mathrm{N}$ and marks a delicate boundary as the southernmost extension of sea-ice in the Northern Hemisphere.

\section{Conclusions}

In this study we have combined new results from stable isotope records and ventilation ages from the northwest Pacific including the Bering Sea and Okhotsk Sea. From this we were able to trace changes in northwest Pacific intermediatewater ventilation on millennial timescales and constrain its source areas during the last deglaciation:

1. The combination of benthic $\delta^{13} \mathrm{C}$-records and ventilation ages from the subarctic northwest Pacific consistently argues for millennial-scale switches in intermediate-water formation during the last deglaciation. Changes in northwest Pacific intermediate water are simultaneous to variations in Atlantic Meridional Overturning Circulation and suggest a deglacial seesaw between strengthened (weakened) intermediatedepth overturning of the subarctic Pacific and weakened (strengthened) meridional overturning of the North Atlantic. The comparison between intermediateand deep-water records provides no evidence for a switch to deep-water formation in the northwest $\mathrm{Pa}$ cific during HS- 1 and YD.

2. The deglacial source of enhanced North Pacific Intermediate Water formation during cold events of HS-1 and YD was most likely within the Okhotsk Sea and coupled to processes of improved OSIW formation, which acted as pacemaker for NPIW changes. It seems also likely that times of enhanced ventilation of the Bering Sea are coupled to more rigorous formation of NPIW.

3. The strengthening of NPIW and intermediate-depth overturning during HS-1 and YD would argue for a deepening of the nutricline within the northwest $\mathrm{Pa}$ cific. A mode of intensified intermediate-depth overturning through enhanced NPIW ventilation in the North Pacific might have reduced the upwelling of old, nutrient and $\mathrm{CO}_{2}$-enriched Pacific deep-water masses and subsequent exchange with the atmosphere, in particular during HS-1. 
Acknowledgements. We gratefully acknowledge the Master and crew of R/V SONNE cruises SO178, SO201-2 and R/V Akademik M. A. Lavrentyev (LV29) and thank for their professional support on-board. We express our thanks to L. Schönborn and G. Meyer for running the mass spectrometer laboratory at AWI stable isotope lab. Samples from this study were collected during German-Russian projects KOMEX-SONNE (03G0178A), KOMEX II (03G0535A), KALMAR (03G0672B and $03 \mathrm{G} 0672 \mathrm{~A}$ ) as well as INOPEX (03G0202A) and funded by the German Federal Ministry of Education and Research (BMBF). The Helmholtz Climate Initiative REKLIM (Regional climate change) funded this study. Supplementary data are available at PANGAEA Data Publisher for Earth \& Environmental Science http://dx.doi.org/10.1594/PANGAEA.830222.

Edited by: L. Skinner

\section{References}

Adkins, J. F. and Boyle, E. A.: Changing atmospheric $\delta^{14} \mathrm{C}$ and the record of deep water paleoventilation ages, Paleoceanography 12, 337-344, 1997.

Ahagon, N., Ohkushi, K., Uchida, M., and Mishima, T.: Mid-depth circulation in the northwest Pacific during the last deglaciation: Evidence from foraminiferal radiocarbon ages, Geophys. Res. Lett., 30, 2097, doi:10.1029/2003GL018287, 2003.

Behl, R. J. and Kennett, J. P.: Brief interstadial events in the Santa Barbara basin, NE Pacific, during the past $60 \mathrm{kyr}$, Nature, 379, 243-246, 1996.

Belanger, P. E., Curry, W. B., and Matthews, R. K.: Core-Top Evaluation of Benthic Foraminiferal Isotopic-Ratios for PaleoOceanographic Interpretations, Palaeogeogr. Palaeocl., 33, 205220, 1981.

Biebow, N., Kulinich, R., and Baranov, B.: KOMEX II, Kurile Okhotsk Sea Marine Experiment: cruise report RV Akademik M. A. Lavrentyev cruise 29, leg 1 and leg 2, in: GEOMARReport 110, edited by: Biebow, N., Kulinich, R., and Baranov, B., Leibniz Institute of Marine Sciences, Kiel, 2002.

Broecker, W., Barker, S., Clark, E., Hajdas, I., Bonani, G., and Stott, L.: Ventilation of the glacial deep Pacific Ocean, Science, 306, 1169-1172, 2004.

Cartapanis, O., Tachikawa, K., and Bard, E.: Northeastern Pacific oxygen minimum zone variability over the past $70 \mathrm{kyr}$ : Impact of biological production and oceanic ventilation, Paleoceanography, 26, PA4208, doi:10.1029/2011PA002126, 2011.

Chikamoto, M. O., Menviel, L., Abe-Ouchi, A., Ohgaito, R., Timmermann, A., Okazaki, Y., Harada, N., Oka, A., and Mouchet, A.: Variability in North Pacific intermediate and deep water ventilation during Heinrich events in two coupled climate models, Deep-Sea Res. P. II, 61-64, 114-126, 2012.

Cook, M. S., Keigwin, L. D., and Sancetta, C. A.: The deglacial history of surface and intermediate water of the Bering Sea, DeepSea Res. Pt. II, 52, 2163-2173, 2005.

Curry, W. B. and Oppo, D. W.: Glacial water mass geometry and the distribution of $\delta^{13} \mathrm{C}$ of Sigma $\mathrm{CO}_{2}$ in the western Atlantic Ocean, Paleoceanography, 20, PA1017, doi:10.1029/2004PA001021, 2005.
Curry, W. B., Duplessy, J. C., Labeyrie, L. D., and Shackleton, N. J.: Changes in the distribution of $\delta^{13} \mathrm{C}$ of deep water $\mathrm{TCO}_{2}$ between the last glaciation and the Holocene, Paleoceanography, 3, 317341, 1988.

Dullo, W. C., Biebow, N., and Georgeleit, K.: SO178-KOMEX Cruise Report: Mass exchange processes and balances in the Okhotsk Sea, in: IFM-GEOMAR Report, edited by: Biebow, N., Leibniz Institute of Marine Sciences, Kiel, 2004.

Dullo, W. C., Baranov, B., and van den Bogaard, C.: FS Sonne Fahrtbericht/Cruise Report SO201-2 KALMAR, Busan/KoreaTomakomai/Japan, 30 August-8 October 2009, in: IFMGEOMAR Report 35, edited by: van den Bogaard, C., Leibniz Institute of Marine Sciences, Kiel, 2009.

Duplessy, J. C., Shackleton, N. J., Matthews, R. K., Prell, W., Ruddiman, W. F., Caralp, M., and Hendy, C. H.: ${ }^{13}$ C Record of Benthic Foraminifera in the Last Interglacial Ocean - Implications for the Carbon-Cycle and the Global Deep-Water Circulation, Quaternary Res., 21, 225-243, 1984.

Duplessy, J. C., Arnold, M., Bard, E., Juilletleclerc, A., Kallel, N., and Labeyrie, L.: Ams ${ }^{14} \mathrm{C}$ Study of Transient Events and of the Ventilation Rate of the Pacific Intermediate Water during the Last Deglaciation. Radiocarbon, 31, 493-502, 1989.

Emile-Geay, J., Cane, M. A., Naik, N., Seager, R., Clement, A. C., and van Geen, A.: Warren revisited: Atmospheric freshwater fluxes and "Why is no deep water formed in the North Pacific", J. Geophys. Res.-Oceans, 108, 3178, doi:10.1029/2001JC001058, 2003.

Erlenkeuser, H. and the TRANSDRIFT II Shipboard Scientific Party: Stable carbon isotope ratios in the waters of the Laptev Sea/Sept, 94, in: Russian-German Cooperation: Laptev Sea System, Berichte zur Polarforschung/Reports on Polar Research 176, edited by: Kassens, H., Piepenburg, D., Thiede, J., Timokhov, L., Hubberten, H.-W., and Priamikov, S. M., Alfred Wegener Institute for Polar and Marine Research, Bremerhaven, 170-177, 1995.

Erlenkeuser, H., Spielhagen, R. F., and Taldenkova, E.: Stable isotopes in modern water and bivalvesamples from the Kara Sea, in: The Kara Sea Expedition of RV Akademik Boris Petrov 1997: First Results of a Joint Russian-German Pilot Study, Berichte zur Polarforschung/Reports on Polar Research 300, edited by: Mathiessen, J., Stepanets, O. V., Stein, R., Fuetterer, D. K., and Galimov, E. M., Alfred Wegener Institute for Polar and Marine Research, Bremerhaven, 80-90, 1999.

Galbraith, E. D., Jaccard, S. L., Pedersen, T. F., Sigman, D. M., Haug, G. H., Cook, M., Southon, J. R., and Francois, R.: Carbon dioxide release from the North Pacific abyss during the last deglaciation, Nature, 449, 890-899, 2007.

Gersonde, R.: The Expedition of the Research Vessel "Sonne" to the Subpolar North Pacific and the Bering Sea in 2009 (SO202INOPEX), in: Report on Polar and Marine Research 643, edited by: Gersonde R., Alfred Wegener Institute for Polar and Marine Research, Bremerhaven, 2012.

Harada, N., Sato, M., Seki, O., Timmermann, A., Moossen, H., Bendle, J., Nakamura, Y., Kimoto, K., Okazaki, Y., Nagashima, K., Gorbarenko, S. A., Ijiiri, A., Nakatsuka, T., Menviel, L., Chikamoto, M. O., Abe-Ouchi, A., and Schouten, S.: Sea Surface temperature changes in the Okhotsk Sea and adjacent North Pacific during the last glacial maximum and deglaciation, DeepSea Res. P. II, 61-64, 93-105, 2012. 
Horikawa, K., Asahara, Y., Yamamoto, K., and Okazaki, Y.: Intermediate water formation in the Bering Sea during glacial periods: Evidence from neodymium isotope ratios, Geology, 38, 435-438, 2010.

Jaccard, S. L. and Galbraith, E. D.: Large climate-driven changes of oceanic oxygen concentrations during the last deglaciation, Nat. Geosci., 5, 151-156, 2012.

Jaccard, S. L. and Galbraith, E. D.: Direct ventilation of the North Pacific did not reach the deep ocean during the last deglaciation, Geophys. Res. Lett., 40, 199-203, 2013.

Keigwin, L. D.: Glacial-age hydrography of the far northwest Pacific Ocean, Paleoceanography, 13, 323-339, 1998.

Keigwin, L. D.: Late Pleistocene-Holocene paleoceanography and ventilation of the Gulf of California, J. Oceanogr., 58, 421-432, 2002.

Kim, S., Khim, B. K., Uchida, M., Itaki, T., and Tada, R.: Millenial-scale paleoceanographic events and implications for the intermediate-water ventilation in the northrn slope area of the Bering Sea during the last 71 kyrs, Global Planet. Change, 79, 89-98, 2011.

Krebs, U. and Timmermann, A.: Tropical air-sea interactions accelerate the recovery of the Atlantic Meridional Overturning Circulation after a major shutdown, J. Climate, 20, 4940-4956, 2007.

Kroopnick, P. M.: The Distribution of ${ }^{13} \mathrm{C}$ of $\Sigma-\mathrm{Co}_{2}$ in the World Oceans, Deep-Sea R. Pt. I, 32, 57-84, 1985.

Kuzmin, Y. V., Burr, G. S., and Jull, A. J. T.: Radiocarbon reservoir correction ages in the Peter the Great Gulf, Sea of Japan, and eastern coast of the Kunashir, southern Kuriles (northwestern Pacific), Radiocarbon 43, 477-481, 2001.

Kuzmin, Y. V., Burr, G. S., Gorbunov, S. V., Rakov, V. A., and Razjigaeva, N. G.: A tale of two seas: Reservoir age correction values $(R, \Delta R)$ for the Sakhalin Island (Sea of Japan and Okhotsk Sea, Nucl. Instrum. Meth. Phys. Res. B, 259, 460-462, 2007.

Luchin, V. A., Menovshchikow, V. A., Lavrentiev, V. M., and Reed, R. K.: Thermohaline structure and water masses in the Bering Sea, in: Dynamics of the Bering Sea, edited by: Loughlin, T. R. and Ohtani, K. University of Alaska Grant, Fairbanks, 61-92, 1999.

Lund, D. C., Mix, A. C., and Southon, J.: Increased ventilation age of the deep northeast Pacific Ocean during the last deglaciation, Nat. Geosci., 4, 771-774, 2011.

Lund, D. C.: Deep Pacific ventilation ages during the last deglaciation: Evaluating the influence of diffusive mixing and source region reservoir age, Earth Planet. Sc. Lett., 381, 52-62, 2013.

Mackensen, A., Schumacher, S., Radke, J., and Schmidt, D. N.: Microhabitat preferences and stable carbon isotopes of endobenthic foraminifera: clue to quantitative reconstruction of oceanic new production?, Mar. Micropaleontol., 40, 233-258, 2000.

Max, L., Riethdorf, J. R., Tiedemann, R., Smirnova, M., LembkeJene, L., Fahl, K., Nurnberg, D., Matul, A., and Mollenhauer, G.: Sea surface temperature variability and sea-ice extent in the subarctic northwest Pacific during the past 15,000 years, Paleoceanography, 27, PA3213, doi:10.1029/2012PA002292, 2012.

McManus, J. F., Francois, R., Gherardi, J. M., Keigwin, L. D., and Brown-Leger, S.: Collapse and rapid resumption of Atlantic meridional circulation linked to deglacial climate changes, Nature, 428, 834-837, 2004.
Menviel, L., Timmermann, A., Timm, O. E., Mouchet, A., AbeOuchi, A., Chikamoto, M. O., Harada, N., Ohgaito, R., snf Okazaki, Y.: Removing the North Pacific halocline: Effects on global climate, ocean circulation and the carbon cycle, Deep-Sea Res. Pt. II, 61-64, 106-113, 2012.

Mikolajewicz, U., Crowley, T. J., Schiller, A., and Voss, R.: Modelling teleconnections between the North Atlantic and North Pacific during the Younger Dryas, Nature, 387, 384-387, 1997.

Minoshima, K., Kawahata, H., Irino, T., Ikehara, K., Aoki, K., Uchida, M., Yoneda, M., and Shibata, Y.: Deep water ventilation in the northwestern North Pacific during the last deglaciation and the early Holocene (15-5 cal. kyr BP) based on AMS ${ }^{14} \mathrm{C}$ dating, Nucl. Instrum. Meth. Phys. Res. B, 259, 448-452, 2007.

Murayama, M., Taira, A., Iwakura, H., Matsumoto, E., and Nakamura, T.: Northwest Pacific deep water ventilation rate during the past 35,000 years with the AMS ${ }^{14} \mathrm{C}$ foraminifera ages, Summaries of Researchers Using AMS at Nagoya University (Nagoya University Center for Chronological Research), Nagoya, Japan, 114-121, 1992.

Okazaki, Y., Timmermann, A., Menviel, L., Harada, N., Abe-Ouchi, A., Chikamoto, M. O., Mouchet, A., and Asahi, H.: Deepwater Formation in the North Pacific During the Last Glacial Termination, Science, 329, 200-204, 2010.

Okazaki, Y., Sagawa, T., Asahi, H., Horikawa, K., and Onodera, J.: Ventilation changes in the western North Pacific since the last glacial period, Clim. Past, 8, 17-24, doi:10.5194/cp-8-17-2012, 2012.

Okazaki, Y., Kimoto, K., Asahi, H., Sato, M., Nakamura, Y., and Harada, N.: Glacial to deglacial ventilation and productivity changes in the southern Okhotsk Sea, Palaeogeogr. Palaeocl., 395, 53-66, 2014.

Okumura, Y. M., Deser, C., Hu, A., Timmermann, A., and Xie, S. P.: North Pacific Climate Response to Freshwater Forcing in the Subarctic North Atlantic: Oceanic and Atmospheric Pathways, J. Climate, 22, 1424-1445, 2009.

Rasmussen, S. O., Andersen, K. K., Svensson, A. M., Steffensen, J. P., Vinther, B. M., Clausen, H. B., Siggaard-Andersen, M. L., Johnsen, S. J., Larsen, L. B., Dahl-Jensen, D., Bigler, M., Rothlisberger, R., Fischer, H., Goto-Azuma, K., Hansson, M. E., and Ruth, U.: A new Greenland ice core chronology for the last glacial termination, J. Geophys. Res.-Atmos., 111, D06102, doi:10.1029/2005JD006079, 2006.

Reimer, P. J., Bard, E., Bayliss, A., Beck, J. W., Blackwell, P. G., Ramsey, C. B., Buck, C. E., Cheng, H., Edwards, R. L., Friedrich, M., Grootes, P. M., Guilderson, T. P., Haflidason, H., Hajdas, I., Hatte, C., Heaton, T. J., Hoffmann, D. L., Hogg, A. G., Hughen, K. A., Kaiser, K. F., Kromer, B., Manning, S. W., Niu, M., Reimer, R. W., Richards, D. A., Scott, E. M., Southon, J. R., Staff, R. A., Turney, C. S. M., and van der Plicht, J.: Intcal13 and Marine13 Radiocarbon Age Calibration Curves 050,000 Years Cal Bp, Radiocarbon, 55, 1869-1887, 2013.

Rella, S. F., Tada, R., Nagashima, K., Ikehara, M., Itaki, T., Ohkushi, K., Sakamoto, T., Harada, N., and Uchida, M.: Abrupt changes of intermediate water properties on the northeastern slope of the Bering Sea during the last glacial and deglacial period, Paleoceanography, 27, PA3203, doi:10.1029/2011PA002205, 2012. 
Riethdorf, J.-R., Nürnberg, D., Max, L., Tiedemann, R., Gorbarenko, S. A., and Malakhov, M. I.: Millennial-scale variability of marine productivity and terrigenous matter supply in the western Bering Sea over the past $180 \mathrm{kyr}$, Clim. Past, 9, 1345-1373, doi:10.5194/cp-9-1345-2013, 2013.

Saenko, O. A., Schmittner, A., and Weaver, A. J.: The AtlanticPacific seesaw, J. Climate, 17, 2033-2038, 2004.

Sagawa, T. and Ikehara, K.: Intermediate water ventilation change in the subarctic northwest Pacific during the last deglaciation, Geophys. Res. Lett., 35, L24702, doi:10.1029/2008GL035133, 2008.

Sarnthein, M., Kiefer, T., Grootes, P. M., Elderfield, H., and Erlenkeuser, H.: Warmings in the far northwestern Pacific promoted pre-Clovis immigration to America during Heinrich event 1 , Geology, 34, 141-144, 2006.

Sarnthein, M., Schneider, B., and Grootes, P. M.: Peak glacial ${ }^{14} \mathrm{C}$ ventilation ages suggest major draw-down of carbon into the abyssal ocean, Clim. Past, 9, 2595-2614, doi:10.5194/cp-92595-2013, 2013.

Schmittner, A., Galbraith, E. D., Hostetler, S. W., Pedersen, T. F., and Zhang, R.: Large fluctuations of dissolved oxygen in the Indian and Pacific oceans during Dansgaard-Oeschger oscillations caused by variations of North Atlantic Deep Water subduction, Paleoceanography, 22, PA3207, doi:10.1029/2006PA001384, 2007.

Shcherbina, A. Y., Talley, L. D., and Rudnick, D. L.:. Direct observations of North Pacific ventilation: Brine rejection in the Okhotsk Sea, Science, 302, 1952-1955, 2003.
Stuiver, M.: Workshop on ${ }^{14} \mathrm{C}$ Data Reporting, Radiocarbon, 22, 964-966, 1980.

Stuiver, M. and Polach, H. A.: Reporting of ${ }^{14} \mathrm{C}$ Data - Discussion, Radiocarbon, 19, 355-363, 1977.

Stuiver, M. and Reimer, P. J.: Extended ${ }^{14} \mathrm{C}$ Data-Base and Revised Calib 3.0 ${ }^{14} \mathrm{C}$ Age Calibration Program, Radiocarbon, 35, 215230, 1993.

Talley, L. D.: Distribution and Formation of North Pacific Intermediate Water, J. Phys. Oceanogr., 23, 517-537, 1993.

Talley, L. D. and Roemmich, D.: A tribute to Reid, Joseph, 1. in recognition of 40 years of contributions to oceanography, DeepSea Res. Pt. I, 38, R7-R11, 1991.

Talley, L. D., Reid, J. L., and Robbins, P. E.: Data-based meridional overturning streamfunctions for the global ocean, J. Climate, 16, 3213-3226, 2003.

Tanaka, S. and Takahashi, K.: Late Quaternary paleoceanographic changes in the Bering Sea and the western subarctic Pacific based on radiolarian assemblages, Deep-Sea Res. Pt. II, 52, 2131-2149, 2005.

Warner, M. J., Bullister, J. L., Wisegarver, D. P., Gammon, R. H., and Weiss, R. F.: Basin-wide distributions of chlorofluorocarbons CFC-11 and CFC-12 in the north Pacific: 1985-1989, J. Geophys. Res.-Oceans, 101, 20525-20542, 1996.

Warren, B. A.: Why Is No Deep-Water Formed in the North Pacific, J. Mar. Res., 41, 327-347, 1983.

Yasuda, I.: The origin of the North Pacific Intermediate Water, J. Geophys. Res.-Oceans, 102, 893-909, 1997. 